\title{
Preparation and Characterization of Mullite-Alumina Structures Formed "In Situ" from Calcined Alumina and Different Grades of Synthetic Amorphous Silica
}

\author{
Leandro Fernandes ${ }^{(\oplus,}$, Rafael Salomão ${ }^{a *(1)}$ \\ ${ }^{a}$ Departamento de Engenharia de Materiais, Escola de Engenharia de São Carlos, Universidade de São \\ Paulo, Avenida Trabalhador São-carlense, 400, São Carlos, SP, Brasil
}

Received: August 30, 2017; Revised: January 29, 2018; Accepted: February 02, 2018

\begin{abstract}
The in situ reaction between alumina and silica to obtain mullite $\left(\mathrm{Al}_{6} \mathrm{Si}_{4} \mathrm{O}_{13}\right)$ can be significantly affected by using synthetic amorphous silica (SAS) sources instead of crystalline ones (quartz and cristobalite). For instance, SASs promote early mullite formation (below $1300^{\circ} \mathrm{C}$ ) and greater densification during sintering. This paper reports the "in situ" formation of mullite-alumina structures from fine calcined alumina $\left(\alpha-\mathrm{Al}_{2} \mathrm{O}_{3}\right)$ and four grades of SAS of different particles' morphology, specific surface area and internal porosity. After sintering assisted by dilatometry (up to $1500^{\circ} \mathrm{C}$ ), the samples' total porosity, density and flexural strength were measured. The relative density and strength levels of some of these structures were greater than or comparable to other studies in which similar compositions were sintered at higher temperatures $\left(1600-1700^{\circ} \mathrm{C}\right)$. Their microstructure assessment indicated that the specific surface area and internal porosity of SAS particles showed a major influence in the development of these physical properties.
\end{abstract}

Keywords: Synthetic amorphous silica, mullite, microstructure, physical properties, calcined alumina, densification.

\section{Introduction}

Mullite $\left(3 \mathrm{Al}_{2} \mathrm{O}_{3} \cdot 2 \mathrm{SiO}_{2}\right.$ or $\left.\mathrm{Al}_{6} \mathrm{Si}_{2} \mathrm{O}_{13}\right)$, one of the main raw materials for the ceramic industry ${ }^{1-4}$, is an input for the production of refractory materials ${ }^{1,5-9}$, catalyst support ${ }^{10,11}$, electronic and optic devices ${ }^{12-14}$, thermal insulators ${ }^{8,9,15}$, hot gas filters (above $\left.600^{\circ} \mathrm{C}\right)^{16-18}$ and biological and biomedical scaffolds ${ }^{19-21}$. Its formation is a complex set of high-temperature $\left(800-1400^{\circ} \mathrm{C}\right)$ solid state reactions ${ }^{22-24}$ between silica $\left(\mathrm{SiO}_{2}\right)$ and alumina $\left(\mathrm{Al}_{2} \mathrm{O}_{3}\right)^{25-29}$ based on the mutual diffusion of $\mathrm{Al}^{3+}, \mathrm{Si}^{4+}$ and $\mathrm{O}^{-2}$ ions amongst particles ${ }^{30-33}$. Various studies have pointed out the characteristics of the silica source (crystallinity ${ }^{35}$, particle size distribution ${ }^{25}$, presence of impurities ${ }^{26,27}$ ) and processing conditions (heating rate ${ }^{28}$, temperature of the thermal treatment ${ }^{29}$ ) affect directly the yield, kinetics and morphology of the products formed ${ }^{2,7-10}$. For instance, reactions between coarse alumina and micronized quartz particles ( $45 \mu \mathrm{m}$ average size) generate porous mullite at temperatures above $1300^{\circ} \mathrm{C}^{9,28,31}$, whereas the combination of finer nanoparticles of alumina and amorphous silica produced by alcoxi-based precursors reduced the range to $800-1100^{\circ} \mathrm{C}$ and promote greater densification ${ }^{35-37}$. Therefore, by changing the characteristics of the silica source, ceramics of different microstructures, porosity levels and thermomechanical properties can be designed.

Amongst the several raw materials available for mullite production, many recent studies have explored the use of

*e-mail: rsalomao@sc.usp.br synthetic amorphous silica (SAS) grades because they are high-purity particles $\left(\mathrm{SiO}_{2}\right.$-content above $\left.97 \%\right)$ of great homogeneity and reproducibility. During the first heating and above the glass transition temperature (typically in the $900-1100^{\circ} \mathrm{C}$ range), their viscous flow behaves as sintering aid enhancing particle densification. SASs particles can be produced in a wide range of characteristics, as shown elsewhere ${ }^{38}$. Its technological importance suggests that it is important to understand how these different physical properties could affect mullite formation. Therefore, in this study, four grades of SAS ${ }^{8,15,38,39}$ (Table 1, Fig. 1) were tested regarding their ability in generating dense structures of in situ mullite after a reaction with fine calcined alumina. They were chosen because they exhibit similar average particle sizes and purity and significant differences in other physical properties, such as a specific surface area and levels of intraparticle mesoporosity.

Silica precipitated from sodium silicate (PS, Fig. 1a) is a commercial additive used as a reinforcing filler for paints, tires and other polymeric composites ${ }^{38,39}$. Its particles are slightly irregular in shape due to the milling and desagglomeration steps involved in their production. At the same time, its physical properties are highly reproducible, such as its specific surface area (above $\left.200 \mathrm{~m}^{2} \cdot \mathrm{g}^{-1}\right)^{39}$. Silica particles extracted from rice husk (RH, Fig. 1c) ${ }^{39-44}$ and rice husk ash

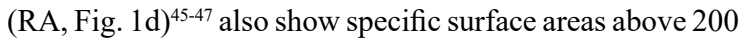
$\mathrm{m}^{2} \cdot \mathrm{g}^{-1}$ and morphology composed of aggregates of $100 \mathrm{~nm}$ average size of primary particles of 20 to $30 \mathrm{~nm}{ }^{47}$.In both cases, besides the low-costs, the presence of a large amount 
Table 1. Characteristics of the raw materials tested.

\begin{tabular}{|c|c|c|c|c|c|}
\hline \multirow[b]{2}{*}{ Characteristics } & \multirow{2}{*}{$\begin{array}{c}\alpha-\mathrm{Al}_{2} \mathrm{O}_{3} \text { source } \\
\text { Calcined alumina } \\
(\mathrm{CA})\end{array}$} & \multicolumn{4}{|c|}{ Synthetic amorphous $\mathrm{SiO}_{2}$ sources } \\
\hline & & $\begin{array}{c}{ }^{b} \text { Precipitated silica } \\
\text { (PS) }\end{array}$ & ${ }^{c}$ Microsilica (MS) & $\begin{array}{c}{ }^{d} \text { Silica from rice } \\
\text { husk }(\boldsymbol{R H})\end{array}$ & $\begin{array}{c}{ }^{e} \text { Silica from rice } \\
\text { husk ash }(\mathrm{RA})\end{array}$ \\
\hline Composition (wt\%) & $\begin{array}{c}\mathrm{Al}_{2} \mathrm{O}_{3}: 99.8 ; \mathrm{Na}_{2} \mathrm{O}: \\
0.05 ; \mathrm{Fe}_{2} \mathrm{O}_{3}: 0.01 \\
\mathrm{CaO}: 0.03 ; \mathrm{MgO}: \\
0.07 ; \mathrm{SiO}_{2}: 0.04\end{array}$ & $\begin{array}{c}\mathrm{SiO}_{2}: 97.8 ; \mathrm{Na}_{2} \mathrm{O}: \\
2.2\end{array}$ & $\begin{array}{c}\mathrm{SiO}_{2}: 94.9 ; \mathrm{Na}_{2} \mathrm{O}: \\
0.2 ; \mathrm{K}_{2} \mathrm{O}: 0.2 ; \mathrm{SO}_{3}: \\
0.2 ; \mathrm{Fe}_{2} \mathrm{O}_{3}: 0.1 ; \\
\mathrm{CaO}: 0.2 ; \mathrm{MgO}: \\
0.2 ; \mathrm{Al}_{2} \mathrm{O}_{3}: 4.0\end{array}$ & $\begin{array}{c}\mathrm{SiO}_{2}: 99.9 ; \mathrm{Na}_{2} \mathrm{O}: \\
0.1\end{array}$ & $\begin{array}{c}\mathrm{SiO}_{2}: 99.0 ; \mathrm{Na}_{2} \mathrm{O}: \\
1.0\end{array}$ \\
\hline $\begin{array}{l}\text { Solid density ( } \rho \text {, } \\
\left.\text { g. } \mathrm{cm}^{-3}\right)\end{array}$ & 3.9 & 2.1 & 2.4 & 2.20 & 2.1 \\
\hline $\begin{array}{l}\text { Specific surface } \\
\text { area }\left(S S A, m^{2} \cdot g^{-1}\right)\end{array}$ & 9.4 & 118 & 24 & 178 & 126 \\
\hline $\begin{array}{l}\text { Total pore volume } \\
\left(T P V, \mathrm{~cm}^{3} \cdot \mathrm{g}^{-1}\right)\end{array}$ & 0.02 & 0.4 & 0.05 & 0.2 & 0.4 \\
\hline $\begin{array}{l}\text { Internal porosity } \\
\text { (IP, \%, Equation 3) }\end{array}$ & 7.8 & 43.2 & 10.7 & 32.7 & 48.7 \\
\hline $\begin{array}{l}\text { Average pore } \\
\text { diameter }(\mathrm{nm})\end{array}$ & 9.4 & 12 & 8.5 & 5 & 15 \\
\hline $\begin{array}{l}\text { Primary particles } \\
\text { average size (nm) }\end{array}$ & 500 & $30-80$ & $50-200$ & $20-30$ & $20-30$ \\
\hline $\begin{array}{l}\text { Clusters average } \\
\text { size }(\mu \mathrm{m})\end{array}$ & Not applicable & $1-6$ & Not applicable & $1-8$ & $1-5$ \\
\hline
\end{tabular}

a) A1000SG, Almatis, Germany; b) Tioxil T300, Solvay-Rhodia Group S/A, Brazil; c) Microsilica 971, Elkem, Norway; d) References ${ }^{40,43}$; e) Reference ${ }^{45}$.
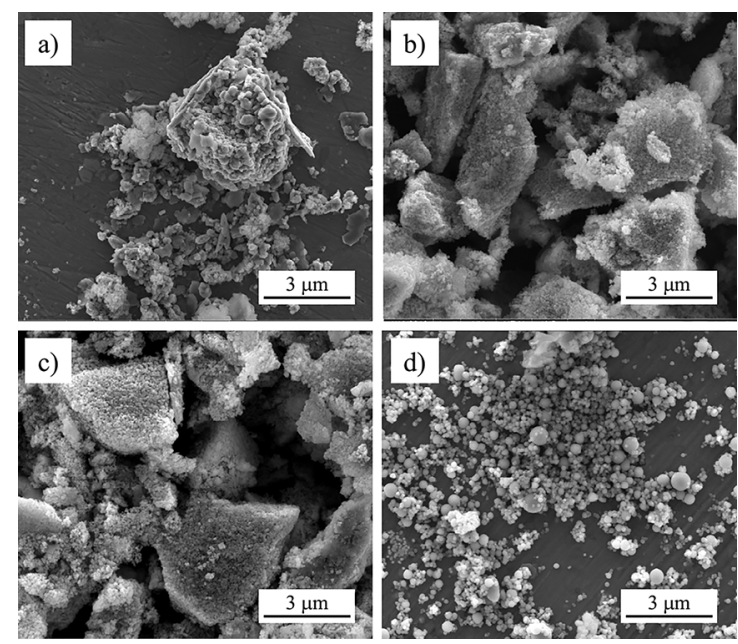

Figure 1. SEM images of the synthetic amorphous silica (SAS) grades tested: a) silica precipitated from sodium silicate (PS), b) silica obtained from rice husks $(\mathrm{RH}), \mathrm{c})$ silica obtained from rice husk ashes (RA), d) microsilica (MS)

of intra-particle mesoporosity suggests that these silica grades can be extremely reactive in contact with calcined alumina at high temperatures. Microsilica (MS, Fig. 1d) particles are spherical, dense and individualized and their broad particle size distribution ranges from 50 to $500 \mathrm{~nm}$. They are obtained as a precipitated by-product during the production of elemental silicon and are widely used in civil construction for enhancing the packing of high performance concrete, and in refractories for the production of mullitebased bricks and castables $1,7,8,15,38,39,48,49$.

After physical characterization, the SAS particles were combined with calcined alumina to produce in situ mullite dense parts. Their sintering behavior was assisted by dilatometry and the products formed were identified by $\mathrm{X}$-ray diffraction and scanning electron microscopy. The physical properties (solid and relative density, total porosity, flexural strength) of the resulting structures were related to the characteristics of the amorphous silica particles.

\section{Materials and Methods}

\subsection{Synthesis and characterization of the particles}

The following raw materials (Table 1) were used: a) calcined alumina (CA, A1000SG, Almatis, Germany), b) silica from the precipitation of sodium silicate (PS, Tixosil T300, Solvay-Rhodia Group S/A, Brazil), c) silica extracted from rice husk $\left(\mathrm{RH}^{43}\right)$, d) silica extracted from rice husk ash $\left(\mathrm{RA}^{43}\right)$, e) silica obtained by the precipitation of oxidized silicon vapor (MS, Microsilica 971, Elkem, Norway), f) organic binder (PVB; Poly(vinyl butyral), Butivar 98, SigmaAldrich, USA) and g) isopropyl alcohol (Synth, Brazil).

The $\mathrm{RH}$ particles ${ }^{40,43}$ were produced initially washing dried rice husks with a $10 \mathrm{wt} \%$ citric acid solution $\left(\mathrm{C}_{6} \mathrm{H}_{8} \mathrm{O}_{7}\right.$; Synth, Brazil) in autoclave (Phoenix Luferco, AV 100 model, 
Brazil) for $1 \mathrm{~h}$ at $127^{\circ} \mathrm{C} \pm 5^{\circ} \mathrm{C}$ and $150 \mathrm{kPa} \pm 20 \mathrm{kPa}$. After neutralization with distilled water and drying $\left(100^{\circ} \mathrm{C} \pm 5^{\circ} \mathrm{C}\right.$ for $12 \mathrm{~h}$ ), the husks were calcined at $700^{\circ} \mathrm{C}$ for 2 hours at $15^{\circ} \mathrm{C} / \mathrm{min}$ heating rate. The calcined material was dry-milled for 2 hours (ball-mill operating at $60 \mathrm{rpm}$ with $\mathrm{ZrO}_{2}$ spheres of $5 \mathrm{~mm}$ diameter; spheres ratio of 10:1 in relation to the dried material).

To obtain RA particles ${ }^{45}$, a suspension containing $0.1 \mathrm{wt} \%$ of rice husk ash in a 2 Mol. $\mathrm{L}^{-1}$ sodium hydroxide $(\mathrm{NaOH})$ solution was heated under reflux conditions for $2 \mathrm{~h}$. The sodium silicate solution formed was filtered to remove the non-reacted ashes, and hydrochloric acid ( $\mathrm{HCl}, 2$ mol.L $\left.\mathrm{L}^{-1}\right)$ was added until $\mathrm{pH}=3$ for the formation of a gel of silica particles, according to Equation 1:

$$
\mathrm{Na}_{2} \mathrm{SiO}_{3}+2 \mathrm{HCl} \rightarrow \mathrm{SiO}_{2(\text { Precipitated })}+2 \mathrm{NaCl}_{(\text {Dissolved })}
$$

RA particles were attained after intensive washing with distilled water for the removal of sodium chloride salt, filtering and drying $\left(2 \mathrm{~h}\right.$ at $\left.110^{\circ} \mathrm{C}\right)$.

Particles samples were previously degassed at $200^{\circ} \mathrm{C}$ for $3 \mathrm{~h}$ in a vacuum atmosphere and then characterized regarding the specific surface area $\left(\mathrm{SSA}, \mathrm{m}^{2} \cdot \mathrm{g}^{-1}\right.$, BET method, ASTM C 1069-09 standard "Standard Test Method for Specific Surface Area of Alumina or Quartz by Nitrogen Adsorption"), total pore volume (TPV, $\mathrm{cm}^{3} \cdot \mathrm{g}^{-1}$, for pores thinner than $50 \mathrm{~nm}$ ) and average pore diameter (PD), by adsorption-desorption isotherms of high-purity $\mathrm{N}_{2}$ (Nova $1200 \mathrm{e}$, Quantachrome Instruments, USA; the ratio between relative pressure, $\mathrm{P}$, and atmospheric pressure, $\mathrm{P}_{0}$, ranged from 0.05 up to 1 ). Their density $\left(\rho,{\mathrm{g} . \mathrm{cm}^{-3}}^{-3}\right)$ was measured by the Helium picnometer method (Ultrapyc 1200e, Quantachrome Instruments, USA).

The particles' internal porosity (IP, \%) is the ratio between the total pore volume inside the particles (TPV) and the total volume of the particles (which corresponds to the sum of TPV and solid volume $)^{39}$. The IP was calculated by Equation 2:

$$
I P(\%)=100 \% \times[(\rho \times T P V) /(\rho \times T P V+1)]
$$

\subsection{Preparation and characterization of mullite samples}

The stoichiometric composition of mullite $\left(3 \mathrm{Al}_{2} \mathrm{O}_{3} \cdot 2 \mathrm{SiO}_{2} .\right)^{22-24}$ was prepared combining the different silica grades (PS, MS, $\mathrm{RH}$ and RA) and calcined alumina (CA) (Fig. 2a-b). The deagglomeration and mixing processes of alumina and silica particles were performed in a ball-mill with a $2 \mathrm{wt} \%$ of PVB isopropyl alcohol suspension containing 33\% solids (grinding specification: $5 \mathrm{~mm}$ diameter zirconia spheres, mass ratio of sphere/powder: 1:3, 2 liters polyethylene flask, $60 \mathrm{rpm}$ for 2 hours; Fig. 2c). The isopropyl alcohol was completely evaporated (Fig. 2d) and the resulting powder was shaped by uniaxial compression (40 MPa, Fig. 2e). The sintering of green samples $(8 \mathrm{~mm}$ length $\times 6 \mathrm{~mm}$ diameter cylinders $)$ was monitored by a $402 \mathrm{C}$ dilatometer (NETZSCH, Germany), under a $5^{\circ} \mathrm{C} / \mathrm{min}$ heating rate up to $1500^{\circ} \mathrm{C}$.

Samples for porosity and mechanical property measurements (bars of $6 \times 20 \times 70 \mathrm{~mm}$ ) were heat-treated at $1100^{\circ} \mathrm{C}$ and $1500^{\circ} \mathrm{C}$ (heating rate of $5^{\circ} \mathrm{C} / \mathrm{min}$, threshold of 2 hours at $400^{\circ} \mathrm{C}$ and $3 \mathrm{~h}$ at the final temperature, $10^{\circ} \mathrm{C} \cdot \mathrm{min}^{-1}$ cooling rate) (Fig. 2f-g). Their relative density (RD, \%) and the total porosity (TP, \%) ${ }^{15,50}$ were calculated using Equations 3 and 4

$$
\begin{gathered}
R D(\%)=100 \% \times(M / L \times W \times T \times \rho) \\
T P(\%)=100-R D
\end{gathered}
$$

M, L, W and T are, respectively, the samples' mass (g) and average length $(\mathrm{cm})$, width $(\mathrm{cm})$ and thickness $(\mathrm{cm})$. The density of these materials $(\rho)$ was measured by the Helium picnometer method in equivalent samples after milling $\left(\mathrm{D}_{\text {Part }} \leq 100 \mu \mathrm{m}\right)$.

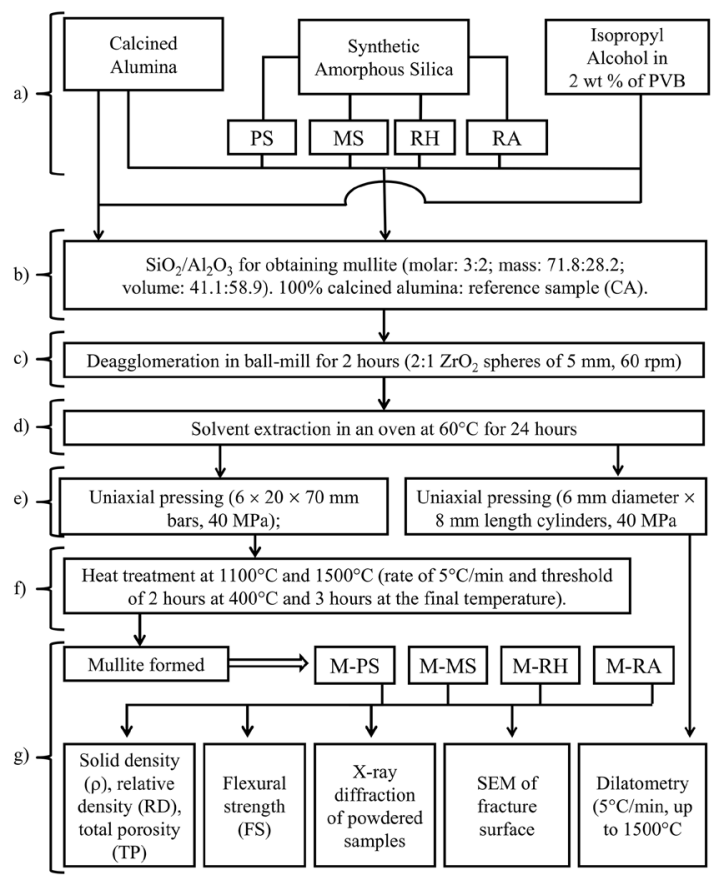

Figure 2. Experimental procedure for the preparation and characterization of in situ mullite-alumina samples

A universal testing machine (WDW-30E, China, 0.5 mm.min ${ }^{-1}$ load application rate) and Equation 5 were used to determine their flexural strength (FS, MPa) by the ThreePoint Bending Test (ASTM C78: "Standard Test Method for Flexural Strength of Concrete Using Simple Beam with Third-Point Loading"):

$$
F S(M P a)=(3 \times F \times S) /\left(2 \times W \times T^{2}\right)
$$


$\mathrm{F}$ is the maximum applied load $(\mathrm{N}), \mathrm{S}$ is the distance between the two supporting points $(\mathrm{m})$, and $\mathrm{W}(\mathrm{m})$ and $\mathrm{T}$ (m) are the average width and thickness of the test sample, respectively. In all cases, five samples were tested for each condition.

The results attained were compared with other similar systems using relative flexural strength (RFS, \%) versus relative density (RD, \%) curves ${ }^{15}$. RFS is the ratio between the experimental results of FS and the theoretical value obtained for a $100 \%$ dense sample (for mullite $2-4,16,30,34,51$, $\mathrm{FS}_{\text {Theoretical }}=180 \mathrm{MPa}$ ). Such an approach is useful for investigating the mechanical behavior of porous $(\mathrm{RD} \leq 50$ $\%)$ and semi-porous structures $(95 \% \leq \mathrm{RD}>50 \%)$. It is based on the fact that, ideally, a reduction in the material's relative density (caused by the introduction of new internal surfaces, as pores) would be followed by a proportional reduction of its mechanical properties. Such a behavior is represented by the $\mathrm{y}=\mathrm{x}$ function. In real cases, however, most commonly, the reduction of the mechanical properties caused by the introduction of porosity is far more intense due to the presence of tensile concentrators and lack of efficient sintering amongst particles ${ }^{15,50}$.

The phases formed during thermal treatment were identified by X-ray diffraction (Rigaku, Rotaflex RV 200B, Japan, pulverized samples). The microstructure of the samples was assessed at fracture surfaces by field emission gun scanning electron microscopy (SEM, FEI, Inspect F50 model, Netherlands).

\section{Results and Discussion}

\subsection{Samples sintered at $1100^{\circ} \mathrm{C}$}

Samples containing precipitated silica $\left(\mathrm{M}-\mathrm{PS}_{1100}\right)$, silica from rice husk $\left(\mathrm{M}-\mathrm{RH}_{1100}\right)$ and silica from rice husk ash (M$\mathrm{RA}_{1100}$ ) showed lower total porosity and flexural strength levels (Fig. 3a) and earlier densification (Fig. 4a-c) than the silica-free reference sample $\left(\mathrm{CA}_{1100}\right)$. Such behavior can be explained analyzing the same flexural strength results as a function of silica particles' internal porosity (IP) (Fig. 3b and Table 1). The particles of these three SAS grades are comprised of nanoclusters strongly aggregated containing large quantity of mesopores amongst them (Fig. 1). These pores are smaller than $30 \mathrm{~nm}$ and are extremely unstable under heating. Due to this, even mild temperatures, such as $400-800^{\circ} \mathrm{C}$ can induce their collapse and early densification of the silica particles ${ }^{39,45}$. The overall effect upon the samples' structure is an intense macroscopic shrinkage and porosity reduction, not necessarily followed by gains of strength.

For microsilica-containing samples $\left(\mathrm{M}-\mathrm{MS}_{1100}\right)$, on the other hand, a different behavior was observed. Comparing
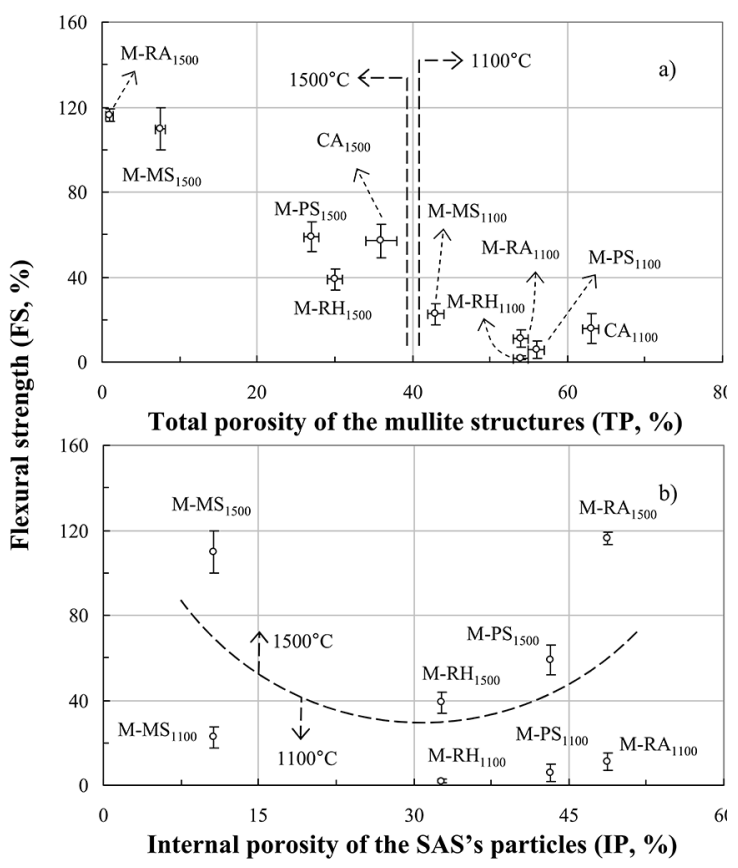

Figure 3. Flexural strength of samples containing different synthetic amorphous silica (SAS) grades thermally treated at $1100^{\circ} \mathrm{C}$ and $1500^{\circ} \mathrm{C}$ as a function of a) total porosity of the structures obtained after sintering and b) SAS particles' internal porosity (IP). The dotted lines are guides to indicate the temperatures of thermal treatment

to the other SAS grades, MS particles have a much lower internal mesoporosity $(\mathrm{IP}=10.7 \%)$ and specific surface area. Due to this, its reduces the amount of voids amongst particles at the compacting step ${ }^{1,6,8,48}$. During the initial heating, no significant densification was observed up to $1000^{\circ} \mathrm{C}$ (Fig. 4d). After sintering at $1100^{\circ} \mathrm{C}, \mathrm{M}-\mathrm{MS}$ samples exhibited the lowest level of porosity and the highest flexural strength amongst the silica-containing-ones. It is also possible that the impurities of the microsilica have generated some small portion of low melting point the liquid phase. They were not detected after cooling in this study but such effect has been already described elsewhere.

No traces of silica crystallization or mullite formation were detected by XRD (Fig. 6) in the samples sintered at $1100^{\circ} \mathrm{C}$. Their fracture surfaces (Fig. 5a-e) are comprised of porous granular packs of individualized particles containing very low necking points. These two aspects indicate that only physical rearrangements, such as pore coalescence or viscous flow ${ }^{8,32,49}$, occurred up to $1100^{\circ} \mathrm{C}$ and that the physical properties of the structures were defined mainly by the calcined alumina matrix behavior.

\subsection{Samples sintered at $1500^{\circ} \mathrm{C}$}

All silica-containing samples sintered at $1500^{\circ} \mathrm{C}$ showed porosity reduction and gains of strength in comparison to those 

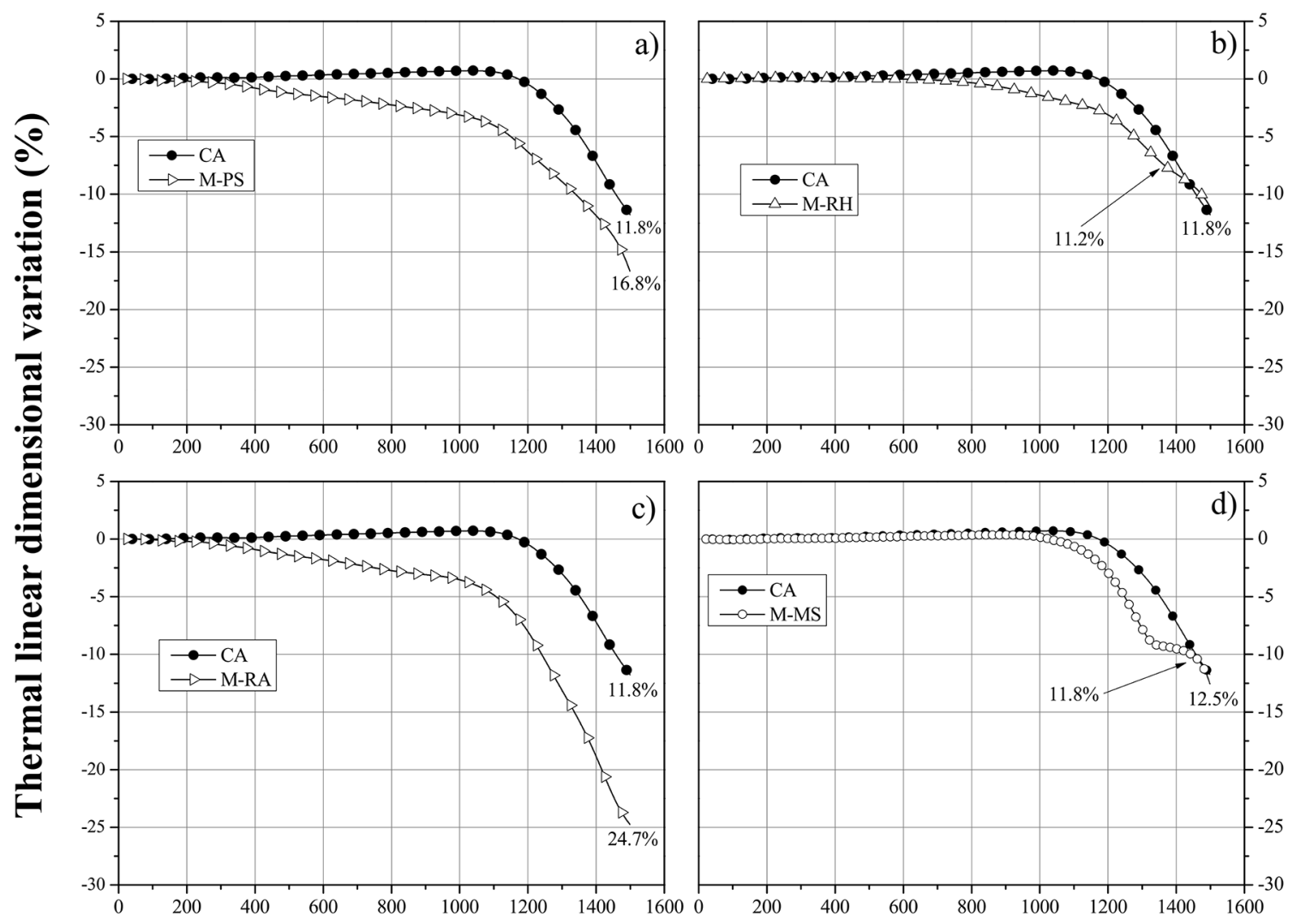

Temperature $\left({ }^{\circ} \mathrm{C}\right)$

Figure 4. Thermal linear variation for samples containing different synthetic amorphous silica (SAS) grades: a) M-PS, b) M-RH, c) M-RA, d) M-MS

thermally treated at $1100^{\circ} \mathrm{C}$ (Fig. 3a). Their microstructure (Fig. 5f-j) evolved to a solid block comprised of mullite (major constituent) and traces of un-reacted corindon and cristobalite (Fig. 6), where evidence of viscous flow can be seen. The dilatometric analysis of the M-PS ${ }_{1500}, \mathrm{M}^{-\mathrm{RH}_{1500}}$ and M-RA ${ }_{1500}$ samples (Fig. 4a-c) revealed total shrinkage levels similar or greater than the one observed for the silicafree reference $\left(\mathrm{CA}_{1500}\right)$. For such compositions, the larger the IP of the silica particles, the more intense the reduction in the structures' total porosity and enhancement of their strength (Fig. 3b).

The densification rate of the M-MS sample was significantly reduced between $1300-1430^{\circ} \mathrm{C}$ (Fig. $4 \mathrm{~d}$ ). This behavior was also observed in other studies ${ }^{8,9,15}$ and can be related to the mullite generation reaction. In comparison to the calcined alumina matrix $\left(\rho=3.8-4 \mathrm{~g} \cdot \mathrm{cm}^{-3}\right)$, the density

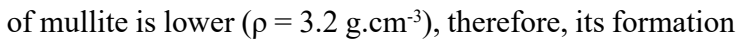
can be followed by a volumetric expansion, depending on the compacting level of the structure. In the present case, since MS improved the initial structure packing efficiency, the formation of mullite partially hindered the particles' densification. However, due to the presence of several alkalibased impurities in the MS composition, it is reasonable to assume the high flexural strength attained is also related to a certain level of liquid sintering.

The comparison between the RFS values of this study to those in other reports (Fig. 7) has shown two important aspects. Firstly, for the range of relative density of $45-99 \%$ tested, the RFS showed a linear variation, which indicates it is possible to tailor such property level depending on the application. For instance, compositions of higher RFS and low porosity, such as M-RA ${ }_{1500}$ and M-MS ${ }_{1500}$, could be used to produce refractory bricks or abrasive tools. On the other hand, those of lower RD (M-RH $\mathrm{RH}_{1100}$ and M-PS $\left.{ }_{1100}\right)$ could be used as porous structures for thermal insulation or as biological scaffolds. Secondly, the overall level of the RFS values obtained in this work is close to those described in the literature for samples of similar compositions, but produced by more complex compaction techniques (isostatic pressing ${ }^{3,10,12}$ ), longer sintering times (longer than $3 \mathrm{~h}^{16,17}$ ) and 

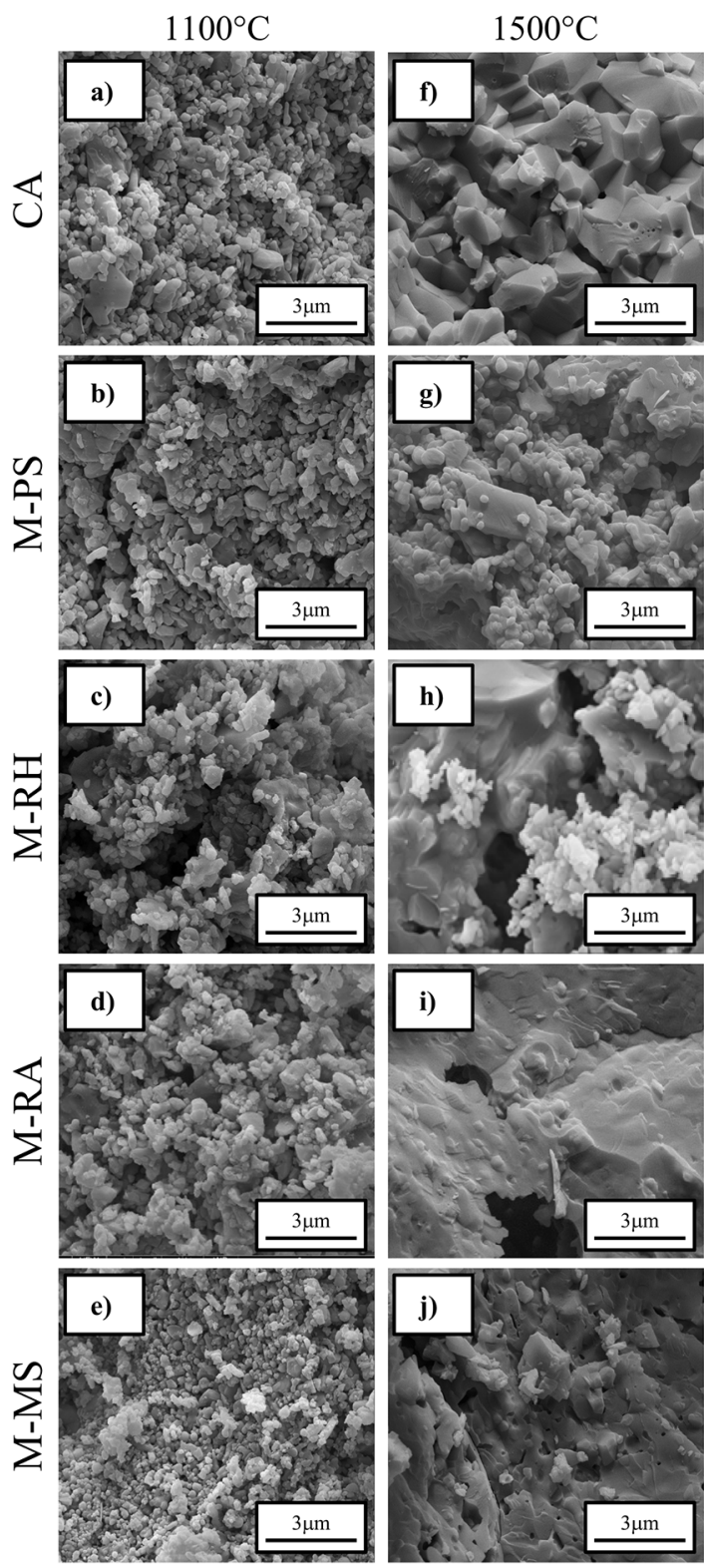

Figure 5. Fracture surfaces of samples treated at $1100^{\circ} \mathrm{C}$ and $1500^{\circ} \mathrm{C}$ for $3 \mathrm{~h}$ (SEM observation)

higher thermal treatment temperatures (above $1500^{\circ} \mathrm{C}^{28,29}$ ) or with the aid of liquid phase sintering ${ }^{27,32}$. Therefore, for similar levels of flexural strength, a significant energy saving in the processing operations could be achieved by using SASs.

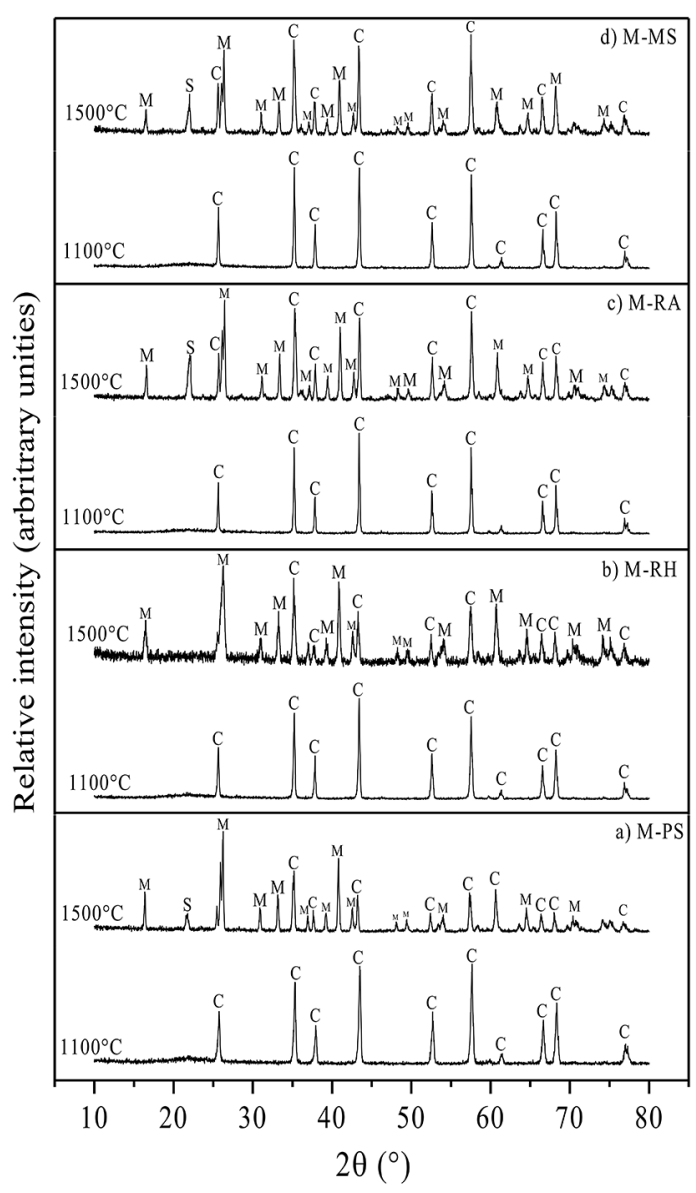

Figure 6. X-ray diffraction patterns for samples treated at $1100^{\circ} \mathrm{C}$ and $1500^{\circ} \mathrm{C}$ for $3 \mathrm{~h}$ : a) M-PS, b) M-RH, c) M-RA, d) M-MS. Crystalline phases (JCPDS file): $\mathrm{C}=$ corundum $\left(\alpha-\mathrm{Al}_{2} \mathrm{O}_{3}, 42-1468\right)$, $\mathrm{S}=$ cristobalite $\left(\mathrm{SiO}_{2}, 39-1425\right), \mathrm{M}=$ mullite $\left(\mathrm{Al}_{6} \mathrm{Si}_{4} \mathrm{O}_{13}, 15-0776\right)$

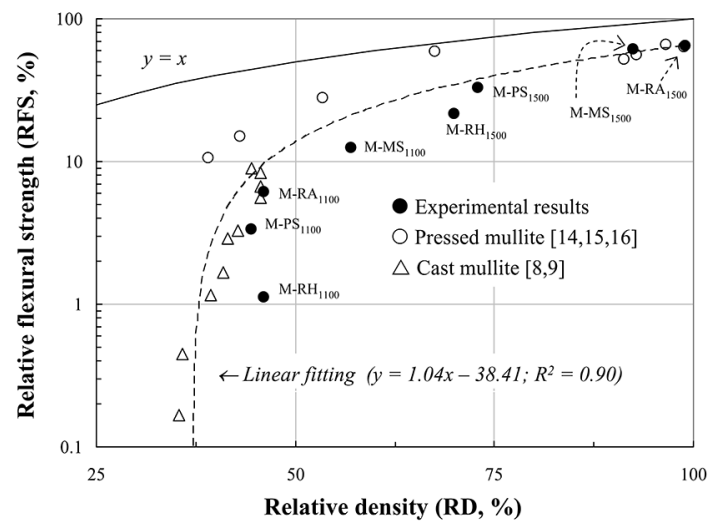

Figure 7. Relative flexural strength (RFS) versus relative density (RD) for samples tested (other results from the literature are also shown on the same basis) 


\section{Conclusions}

The internal porosity and specific surface area of the synthetic amorphous silica (SAS) particles tested significantly impacted the development of microstructure and physical properties of the alumina-mullite structures attained. Two opposite effects were observed.

Firstly, samples containing SAS grades of high internal porosity (silica precipitated from sodium silicate, silica obtained from rice husk, and silica obtained from rice husk ashes) experienced a significant shrinkage between 400$800^{\circ} \mathrm{C}$. At this temperature range, the mesopores located inside the particles of silica collapsed increasing their density and the overall packing efficiency of the system. As a consequence, after sintering at $1500^{\circ} \mathrm{C}$, structures of very low total porosity and high flexural strength were attained. The comparison with other reports in literature showed that the strength levels attained were similar to other systems sintered at higher temperatures for longer periods. This aspect is technologically important because these compositions could replace conventional materials and produce a significant energy saving during the thermal treatment. Secondly, for samples containing the silica grade of very low internal porosity and specific surface area (microsilica), the spherical shape of such particles improved packing efficiency during the pressing step. Due to this, comparing to the other SAS grades, the microsilica-containing structures presented lower porosity and higher strength after sintering at $1100^{\circ} \mathrm{C}$. Besides this, such samples also showed lower densification rate and total linear shrinkage. This effect was attributed to the formation of mullite, which is can be an expansive reaction, when it occurs in a dense structure.

After sintering at $1500^{\circ} \mathrm{C}$, all the samples exhibited a dense microstructure containing signals of viscous flow and were comprised mainly of mullite and small portions of un-reacted corindon $\left(\alpha-\mathrm{Al}_{2} \mathrm{O}_{3}\right)$. It is possible that the crystallization of the SAS particles may have hindered the total conversion of the reactants in mullite or would require longer thermal treatment periods. These aspects are currently under investigation in authors' research group.

\section{Acknowledgements}

Authors acknowledge the Brazilian Research Foundations FAPESP (2010/19274-5) and CNPq (308762/2014-2, 455861/2014-5, 870346/1997-0) for supporting this work, and Solvay-Rhodia Group S/A (Brazil), Almatis (Brazil, USA and Germany) and Elkem (Norway) for supplying samples of raw materials. They are also indebted to Prof. Dr. J.M.D. Rollo, P.L. di Lorenzo and J.J. Bernardi (SMM/ EESC) for assistance in dilatometry and mechanical tests and Wagner R. Correr, MSc. (Microscopy Laboratory, CTMH SMM-EESC/IFSC) for SEM images.

\section{References}

1. Nishikawa A. Technology of Monolithic Refractories. Tokyo: Plibrico Japan Co. Ltd; 1984.

2. Anggono J. Mullite Ceramics: Its Properties, Structure, and Synthesis. Jurnal Teknik Mesin. 2005;7(1):1-10.

3. Schneider H, Schreuer J, Hildmann B. Structure and properties of mullite-A review. Journal of the European Ceramic Society. 2008;28(2):329-344.

4. Schneider H, Fischer RX, Schreuer J. Mullite: Crystal Structure and Related Properties. Journal of the American Ceramic Society. 2015;98(10):2948-2967.

5. Dokko PC, Pask JA, Mazdiyasni KS. High-Temperature Mechanical Properties of Mullite Under Compression. Journal of the American Ceramic Society. 1977;60(3-4):150-155.

6. Ismael MR, Salomão R, Pandolfelli VC. Refractory Castables Based on Colloidal Silica and Hydratable Alumina. American Ceramic Society Bulletin. 2007;86(9):58-62.

7. Salomão R, Souza ADM, Fernandes L, Arruda CC. Advances in nanotechnology for refractories: When very small meets hot, heavy, and large. American Ceramic Society Bulletin. 2013;92(7):22-27.

8. Sousa LL, Souza ADV, Fernandes L, Arantes VL, Salomão R. Development of densification-resistant castable porous structures from in situ mullite. Ceramics International. 2015;41(8):94439454.

9. Sousa LL, Salomão R, Arantes VL. Development and characterization of porous moldable refractory structures of the alumina-mullite-quartz system. Ceramics International. 2017;43(1 Pt B):1362-1370.

10. Hamano K, Sato T, Nakagawa Z. Properties of Mullite Prepared by Co-Precipitation and Microstructure of Fired Bodies. Journal of the Ceramic Association. 1986;94(1092):818-822.

11. Montanaro L, Tulliani JM, Perrot C, Negro A. Sintering of industrial mullites. Journal of the European Ceramic Society. 1997;17(14):1715-1723.

12. Prochazka S, Klug FJ. Infrared-transparent mullite ceramic. Journal of the American Ceramic Society. 1983;66(12):874-880.

13. Aksay IA, Dabbs DM, Sarikaya M. Mullite for Structural, Electronic, and Optical Applications. Journal of the American Ceramic Society. 1991;74(10):2343-2358.

14. Zhang L, Olhero S, Ferreira JMF. Thermo-mechanical and hightemperature dielectric properties of cordierite-mullite-alumina ceramics. Ceramics International. 2016;42(15):16897-16905.

15. Salomão R, Fernandes L. Porous co-continuous mullite structures obtained from sintered aluminum hydroxide and synthetic amorphous silica. Journal of the European Ceramic Society. 2017;37(8):2849-2856.

16. She JH, Ohji T. Fabrication and characterization of highly porous mullite ceramics. Materials Chemistry and Physics. 2003;80(3):610-614.

17. Fukushima M, Yoshizawa YI. Fabrication and morphology control of highly porous mullite thermal insulators prepared by gelation freezing route. Journal of the European Ceramic Society. 2016;36(12):2947-2953. 
18. Arzani M, Mahdavi HR, Bakhtiari O, Mohammadi T. Preparation of mullite ceramic microfilter membranes using Response surface methodology based on central composite design. Ceramics International. 2016;42(7):8155-8164.

19. Nath S, Dey A, Mukhopadhyay AK, Basu B. Nanoindentation response of novel hydroxyapatite-mullite composites. Materials Science and Engineering: A. 2009;513-514:197-201.

20. Nath S, Basu B, Mohanty M, Mohanan PV. In vivo response of novel calcium phosphate-mullite composites: Results up to 12 weeks of implantation. Journal of Biomedical Materials Research - Part B Applied Biomaterials. 2009;90B(2):547-557.

21. Nath S, Dubey AK, Basu B. Mechanical properties of novel calcium phosphate-mullite biocomposites. Journal of Biomaterials Applications. 2012;27(1):67-78.

22. Davis RF, Pask JA. Diffusion and Reaction Studies in the System $\mathrm{Al}_{2} \mathrm{O}_{3}-\mathrm{SiO}_{2}$. Journal of the American Ceramic Society. 1972;55(10):525-531.

23. Risbud SH, Pask JA. Mullite Crystallization from $\mathrm{SiO}_{2}-\mathrm{Al}_{2} \mathrm{O}_{3}$ Melts. Journal of the American Ceramic Society. 1978;61(12):63-67.

24. Aksaf LA, Pask JA. Stable and Metastable Equilibria in the System $\mathrm{SiO}_{2}-\mathrm{Al}_{2} \mathrm{O}_{3}$. Journal of the American Ceramic Society. 1975;58(11-12):507-512.

25. Farenholtz WG, Smith DM, Cesarano J III. Effect of Precursor Particle Size on the Densification and Crystallization Behavior of Mullite. Journal of the American Ceramic Society. 1993;76(2):433-437.

26. Pask JA. Importance of starting materials on reaction and phase equilibria in the $\mathrm{Al}_{2} \mathrm{O}_{3}-\mathrm{SiO}_{2}$ system. Journal of the European Ceramic Society. 1996;16(2):101-108.

27. Chen CY, Lan GS, Tuan WH. Preparation of mullite by the reaction sintering of kaolinite and alumina. Journal of the European Ceramic Society. 2000;20(14-15):2519-2525.

28. Kara F, Little JA. Sintering behaviour of precursor mullite powders and resultant microstructures. Journal of the European Ceramic Society. 1996;16(6):627-635.

29. Yang F, Li C, Lin Y, Wang CA. Effects of sintering temperature on properties of porous mullite/corundum ceramics. Materials Letters. 2012;73:36-39.

30. Kanzaki S, Tabata H, Kumazawa T, Ohta S. Sintering and Mechanical Properties of Stoichiometric Mullite. Journal of the American Ceramic Society. 1985;68(1):C6-C7.

31. Saruhan B, Albers W, Schneider H, Kaysser WA. Reaction and sintering mechanisms of mullite in the systems cristobalite $\alpha$ $\mathrm{Al}_{2} \mathrm{O}_{3}$ and amorphous $\mathrm{SiO}_{2} /-\mathrm{Al}_{2} \mathrm{O}_{3}$. Journal of the European Ceramic Society. 1996;16(10):1075-1081.

32. Rani DA, Jayaseelan DD, Gnanam FD. Densification behaviour and microstructure of gel-derived phase-pure mullite in the presence of sinter additives. Journal of the European Ceramic Society. 2001;21(12):2253-2257.

33. Fielitz P, Borchardt G, Schneider H, Schmücker M, Wiedenbeck M, Rhede D. Self-diffusion of oxygen in mullite. Journal of the European Ceramic Society. 2001;21(14):2577-2582.
34. Ismail MGMU, Nakai Z, Somiya S. Microstructure and Mechanical Properties of Mullite Prepared by the Sol-Gel Method. Journal of the American Ceramic Society. 1987;70(1):C7-C8.

35. Bartsch M, Saruhan B, Schmücker M, Schneider H. Novel Low-Temperature Processing Route of Dense Mullite Ceramics by Reaction Sintering of Amorphous $\mathrm{SiO}_{2}$-Coated $\gamma-\mathrm{Al}_{2} \mathrm{O}_{3}$ Particle Nanocomposites. Journal of the American Ceramic Society. 1999;82(6):1388-1392.

36. Cividanes LS, Campos TMB, Rodrigues LA, Brunelli DD, Thim GP. Review of mullite synthesis routes by sol-gel method. Journal of the Sol-Gel Science and Technology. 2010;55(1):111125.

37. Buljan I, Kosanovic C, Kralj D. A novel synthesis of nano-sized mullite from aluminosilicate precursors. Journal of Alloys and Compouds. 2011;509(32):8256-8261.

38. Iler RK. The Chemistry of Silica: Solubility, Polymerization, Colloid and Surface Properties and Biochemistry. New York: Wiley; 1979.

39. Fernandes L, Arruda CC, Souza ADV, Salomão R. Characterization of Synthetic Amorphous Silica (SAS) Used in the Ceramic Industry. Interceram. 2014;63(4):220-224.

40. Real C, Alcalá MD, Criado JM. Preparation of Silica from Rice Husks. Journal of the American Ceramic Society. 1996;79(8):2012-2016.

41. Yalçin N, Sevinç V. Studies on silica obtained from rice husk. Ceramics International. 2001;27(2):219-224.

42. Chandrasekhar S, Satyanarayana KG, Pramada PN, Raghavan P, Gupta TN. Review Processing, properties and applications of reactive silica from rice husk-an overview. Journal of Materials Science. 2003;38(15):3159-3168.

43. Fernandes L, Sabino MG, Rosseto HL. Method of extration of silica from rice hull. Cerâmica. 2014;60(353):160-163.

44. Kaviyarasu K, Manikandan E, Kennedy J, Jayachandran M, Maaza M. Rice husks as a sustainable source of high quality nanostructured silica for high performance Li-ion battery requital by sol-gel method - A Review. Advanced Materials Letters. 2016;7:122-134.

45. Shelke VR, Bhagade SS, Mandavgane SA. Mesoporous Silica from Rice Husk Ash. Bulletin of Chemical Reaction Engineering \& Catalysis. 2010;5(2):63-67.

46. Ma X, Zhou B, Gao W, Qu Y, Wang L, Wang Z, et al. A recyclable method for production of pure silica from rice hull ash. Powder Technology. 2012;217:497-501.

47. Cheah WK, Ooi CH, Yeoh FY. Rice husk and rice husk ash reutilization into nanoporous materials for adsorptive biomedical applications: A review. Mesoporous Biomaterials. 2016;3(1):2738 .

48. Salomão R, Pandolfelli VC. Microsilica Addition as an Antihydration Technique for Magnesia-Containing Refractory Castables. American Ceramic Society Bulletin. 2007;86(6):93019309.

49. Khattab RM, El-Rafei AM, Zawrah MF. In situ formation of sintered cordierite-mullite nano-micro composites by utilizing of waste silica fume. Materials Research Bulletin. 2012;47(9):2662-2667. 
50. Souza ADV, Sousa LL, Fernandes L, Cardoso PHL, Salomao R. $\mathrm{Al}_{2} \mathrm{O}_{3}-\mathrm{Al}(\mathrm{OH})_{3}$-Based castable porous structures. Journal of the European Ceramic Society. 2015;35(6):1943-1954.
51. Mah TI, Mazdiyasni KS. Mechanical properties of mullite. Journal of the American Ceramic Society. 1983;66(10):699-703. 